\title{
Site U1360
}

\author{
Expedition 318 Scientists $^{2}$
}

\section{Chapter contents}

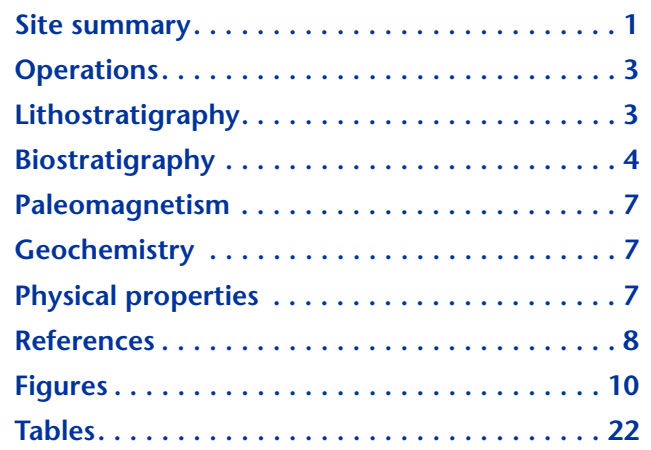

'Expedition 318 Scientists, 2011. Site U1360. In Escutia, C., Brinkhuis, H., Klaus, A., and the Expedition 318 Scientists, Proc. IODP, 318: Tokyo (Integrated Ocean Drilling Program Management International, Inc.).

doi:10.2204/iodp.proc.318.108.2011

'Expedition 318 Scientists' addresses.

\section{Site summary}

Integrated Ocean Drilling Program Site U1360 (proposed Site WLSHE-09B) is on the continental shelf off the Adélie Coast (Fig. F1) at 495 meters below sea level. The main objective at Site U1360 was to core across regional unconformity WL-U3 to determine the timing and nature of the first arrival of the ice sheet to the Wilkes Land Continental Margin. Site U1360 lies at the eastern edge of the Adélie Bank and receives drainage from the East Antarctic Ice Sheet (EAIS) through the Wilkes subglacial basin (see the "Expedition 318 summary" chapter). Glacier ice and the entrained debris draining through the basin and extending to the continental shelf would provide evidence for a large-scale ice sheet on Antarctica.

Regional unconformity WL-U3 was interpreted to record the first expansion of the EAIS across the shelf in this sector of the East Antarctic margin and therefore to separate preglacial strata below from glacial strata above (Eittreim et al., 1995; Escutia et al., 1997; De Santis et al., 2003). Drilling in Prydz Bay during Ocean Drilling Program (ODP) Leg 188 (O'Brien, Cooper, Richter, et al., 2001) and results from Deep Sea Drilling Project Leg 28 Site 269 (Hayes, Frakes, et al., 1975), ODP Leg 189 sites in the Tasman Gateway (Exon, Kennett, Malone, et al., 2001), and ODP Leg 182 Site 1128 in the Great Australian Bight (e.g., Mallinson et al., 2003), among others, led Escutia et al. (2005) to postulate an early Oligocene age (i.e., 33.5-30 Ma) for the development of unconformity WL-U3.

At Site U1360, unconformity WL-U3 was predicted to occur at 165 meters below seafloor (mbsf) (0.81 s two-way traveltime) (Fig. F2). Multichannel seismic reflection profiles crossing Site U1360 show gently dipping strata on the shelf truncated near the seafloor (Fig. F2). This provides a unique opportunity to sample across the unconformity with very shallow penetration. The proximal record from Site U1360 will complement the distal record of the first arrival of the EAIS to the Wilkes Land margin obtained at Site U1356.

Hole U1360A was drilled to a total depth of 70.8 mbsf using the rotary core barrel (RCB) system. Only $60 \mathrm{~cm}$ was recovered in the upper $14.3 \mathrm{mbsf}$, and sediments are unconsolidated and moderately to strongly disturbed by drilling (Core 318-U1360A-1R). Below 14.3 mbsf (Cores $2 \mathrm{R}$ through $6 \mathrm{R}$ ), the sediments are consolidated and most recovered intervals are only slightly disturbed by drilling. Based on visual core descriptions and smear slide analyses, 
cores from Hole U1360A are composed of diamictons, mudstones, sandstones, and diamictites that are placed into two lithostratigraphic units. Unit I (0-14.3 mbsf) consists of unconsolidated clast-rich sandy diamicton (Fig. F3). The diamicton is slightly compacted but soft and crudely stratified and includes one lamination of yellowish clay-rich diatom ooze in interval 318-U1360A-1R-1, 18-20 cm. A trace of diatoms is present in the matrix of the diamictite. Rare shell fragments are also present in this unit. Clast percentages are as high as $25 \%$, and clasts are primarily composed of angular, indurated, olivegreen to olive-brown mudstone fragments, $2-8 \mathrm{~mm}$ in size. Crystalline rock clasts, including basalt and gneiss and as large as $7 \mathrm{~cm}$, have subrounded and faceted shapes. The unconsolidated diamictons were probably deposited from floating ice and most likely represent deposition from a floating glacier tongue or icebergs releasing debris over the site. The lamination of diatom ooze is indicative of a brief period of open-marine conditions with high productivity and low terrigenous sedimentation rates.

The top of Unit II (at 14.3 mbsf) marks a sharp change in lithology and induration of the cores, from unconsolidated diamicton above to carbonatecemented claystone below. An early Oligocene age is assigned to the interval below interval 318-U1360A$3 \mathrm{R}-1,8 \mathrm{~cm}$, whereas no age assignment is possible for Core 318-U1360A-2R (see "Biostratigraphy"). Five different lithofacies are recognized in a sequence from top to bottom in this unit:

1. Olive-green claystone with moderate bioturbation,

2. Dark green claystone with dispersed clasts,

3. Dark greenish gray sandy mudstone with dispersed clasts (Fig. F4),

4. Olive-brown sandstone with dispersed clasts (Fig. F5), and

5. Gray clast-rich sandy diamictite (Fig. F6).

Overall, Unit II can be characterized as a fining-upward sequence from diamictite at the base to claystone at the top. Bivalve shell fragments, some of which are pyritized, are common in the lower portion of Unit II. The lithofacies distribution is consistent with an ice-proximal to ice-distal glaciomarine depositional environment, similar to that described from the Oligocene and Miocene strata of the Victoria Land Basin, Ross Sea, Antarctica (Naish et al., 2001; Powell and Cooper, 2002). Five samples from Hole U1360A were prepared for X-ray diffraction (XRD) analysis of the clay fraction. A mixture of all the major clay mineral groups characterizes the clay mineral assemblages in these samples. The dominant clay mineral components are smectite, illite, and chlorite, with a lesser contribution of kaolinite and pyrophyllite-talc (Fig. F7). The cores assigned to the early Oligocene have clay mineral assemblages similar to those reported from lower Oligocene shelf strata around the Antarctic margin (e.g., Hambrey et al., 1991; Ehrmann et al., 2005). The abundance of illite and chlorite are consistent with a glacial-marine depositional setting for the claystone, mudstone, sandstone, and diamictite facies described within lithostratigraphic Unit II. The relatively large contribution of talc, however, is not typical of Paleogene sediments on the Antarctic shelf and may reflect the weathering of a low-grade metamorphic facies, derived from a basic or ultrabasic igneous protolith, locally on the Wilkes Land margin or within the Wilkes subglacial basin.

Dinoflagellate cysts (dinocysts) and diatoms provide age control for Hole U1360A. They suggest that Core 318-U1360A-1R (0-0.54 mbsf) comprises an uppermost Pleistocene matrix with intraclasts of upper Eocene to lower Oligocene material. An age could not be assigned to the strata between Section 318U1360A-1R-CC and interval 318-U1360A-3R-1, $8 \mathrm{~cm}$ (0.54-23.38 mbsf), because of poor recovery. Samples 318-U1360A-3R-1, $8 \mathrm{~cm}$, to 6R-CC (23.38-53.78 mbsf) are of early Oligocene $(<33.6 \mathrm{Ma})$ age.

Sediments within Core 318-U1360A-1R (0-0.54 mbsf) comprise an uppermost Pleistocene matrix with intraclasts of late Eocene to early Oligocene age. Diatoms indicate that during the latest Pleistocene, the shelf at Hole U1360A was not subjected to year-round ice cover but was influenced by seasonal sea ice either directly or indirectly. Combined microfossil analyses allow the interval below 318-U1360A-3R-1, $8 \mathrm{~cm}$ (23.38 mbsf), to be assigned to the early Oligocene $(<33.6 \mathrm{Ma})$ with confidence. Since these are derived from the same lithostratigraphic Unit II as strata between 14.3 and $23.38 \mathrm{mbsf}$, the entire Unit II is considered to be of early Oligocene. Early Oligocene microfossils indicate a shallow-water shelf environment with low salinities and high nutrient levels, likely driven by seasonal sea ice. Sporomorphs may represent reworking from older strata and/or contemporaneous vegetation in the hinterland.

Two samples from cores of Hole U1360A (Samples 318-U1360A-4R-1, $15 \mathrm{~cm}$, and 4R-2, $72 \mathrm{~cm}$ ) have reverse polarity, consistent with the age of Chron $\mathrm{C} 12 \mathrm{r}$ as indicated by the biostratigraphy (see "Biostratigraphy").

The fining-upward sequence from diamictites at the base (Core 318-U1360A-6R) to claystones at the top (Cores 2R through 3R) (see "Lithostratigraphy") is also documented in the general decrease in magnetic susceptibility values from the bottom to the top of the hole. Variations in gamma ray attenuation (GRA) density nicely reflect variations in lithology between clast-rich diamictite, sandy mudstone with dispersed clasts, and claystone. Calculated porosity ranges 
from $49 \%$ to $17 \%$ and generally decreases with depth. Grain densities range from 2.62 to $2.7 \mathrm{~g} / \mathrm{cm}^{3}$.

\section{Operations}

\section{Transit to Site U1360}

We departed for Site U1360 at 2345 h on 11 February 2010 after coring Hole U1359C. The voyage began in gale force winds and rough seas, but these slowly abated during the day. As we moved south, we began to observe numerous icebergs and had to adjust speed and heading to adapt to conditions. Approximately $15 \mathrm{nmi}$ from location we encountered an ice tongue comprised of pack ice and icebergs that blocked direct access to Site U1360. We had to detour $\sim 30 \mathrm{nmi}$ to the west to find a clear passage around the ice. The outside temperature of $-5^{\circ} \mathrm{C}$ combined with the $35 \mathrm{kt}$ winds created a wind chill of about $-20^{\circ} \mathrm{C}$ and ice began forming on the deck and the outside bulkheads. All times in this section are given in local ship time, which was Universal Time Coordinated $+11 \mathrm{~h}$.

\section{Site U1360}

We arrived at Site U1360 at 1800 h on 12 February 2010. However, we had to wait $5.25 \mathrm{~h}$ in dynamic positioning mode for two large icebergs in the immediate vicinity to move away. We were finally on site and started deploying the drill sting at $2315 \mathrm{~h}$ on 13 February (Table T1). We decided to use a shorter, twostand bottom-hole assembly so we could reduce the time the rigid drill collars were above the seafloor. We did this to reduce the chances of repeating the drill collar pin failure that occurred in Hole U1358B.

After the driller tagged seafloor with the bit at 506.0 meters below rig floor, we started RCB coring in Hole U1360A at $0425 \mathrm{~h}$ on 13 February. Cores 318U1360A-1R through 7R penetrated to $70.8 \mathrm{mbsf}$ and recovered $7.04 \mathrm{~m}(10 \%)$. Because of the relatively hard seafloor, rotary coring proceeded slowly and carefully. Coring had to stop when large icebergs forced an early termination of the hole. We started to prepare a free-fall funnel so that we could attempt to return to the same hole after the next severe storm. Unfortunately, the hole had to be abandoned because of the approaching iceberg before it could be deployed.

We departed Site U1360 at 0615 h on 14 February. We planned on returning to this site, but moved to deeper water to avoid riding out the next intense low pressure system among the ice in shallow water. This system was predicted to arrive on the evening of 14 February with predictions for $50 \mathrm{kt}$ winds (gusts up to $60 \mathrm{kt}$ ) and poor visibility in snow flurries on Monday.
We arrived at a position in deeper water that was $50 \mathrm{nmi}$ north of the ice pack. The $104 \mathrm{nmi}$ transit to this location took $10.2 \mathrm{~h}$ at $10.2 \mathrm{kt}$. We then went into dynamic positioning mode to safely ride out the storm. The storm system arrived as predicted late Sunday evening and by Monday was upon us with sustained winds of $50 \mathrm{kt}$ and gusts as high as $62 \mathrm{kt}$ as well as heavy seas and poor visibility during periods of heavy snow. The sea and swell continued to build during most of 15 February with the vessel motion reflecting the intensity of a storm that increased to just short of hurricane force. The barometer bottomed out at 972 mbar and remained there for the rest of the afternoon. At $1800 \mathrm{~h}$ on 15 February, we had to offset the ship because of an approaching iceberg. The storm began to abate during the late evening and we began the transit back to Site U1360 early the next morning (1000 h on 16 February).

During the transit, we adjusted speed and course so that we would not overtake the remnants of the storm that was still south of us and so that we would arrive at first light the next morning. During the daylight hours of 17 February, we made four attempts to penetrate the northern edge of the extensive pack ice and iceberg barrier that existed between the vessel and Site U1360. However, each time we were blocked by the ice and had to reverse course. So that we could avoid having to maneuver the vessel amidst the ice during the darkness, we moved to a position $\sim 100 \mathrm{nmi}$ northwest of Site U1360 and "parked" in dynamic positioning mode throughout the evening of 17 February.

The next morning we decided to attempt to reach Site U1360 from the south. We began the transit at $0545 \mathrm{~h}$ on 18 February. We sailed around the western edge of the growing ice tongue, then moved eastsoutheast past the Antarctic Circle at $1340 \mathrm{~h}$ and attempted to approach Site U1360 from the southwest. This time we were able to get within $8 \mathrm{nmi}$ of Site U1360 before encountering a heavy concentration of pack ice and icebergs blocking access to the site. We reluctantly reversed course and began retracing our course westward in order to move back around to the northern edge of the ice tongue during the evening of February 18. At this point, we decided to attempt to get to Site U1358 or other alternate sites on the outer shelf on the northern edge of the ice tongue.

\section{Lithostratigraphy}

Only $60 \mathrm{~cm}$ of sediment was recovered in the upper $14.3 \mathrm{mbsf}$ of Hole U1360A (Core 318-U1360A-1R) The recovered sediments are unconsolidated and moderately disturbed by drilling. Below $14.3 \mathrm{mbsf}$ 
(Cores 2R through 6R), sediments are consolidated and most recovered intervals are only slightly disturbed by drilling. Based on visual core descriptions and smear slide analyses, cores from Hole U1360A are composed of diamictons, mudstones, sandstones, and diamictites that are placed into two lithostratigraphic units.

\section{Unit descriptions}

\section{Unit I}

Interval: 318-U1360A-1R-1, $0 \mathrm{~cm}$, through 2R-1, $0 \mathrm{~cm}$

Depth: 0-14.3 mbsf

Age: latest Pleistocene

Unit I consists of unconsolidated clast-rich sandy diamicton (Fig. F3). The diamicton is slightly compacted but soft and crudely stratified and includes one lamination of yellowish clay-rich diatom ooze at interval 318-U1360A-1R-1, $18-20 \mathrm{~cm}$. A trace of diatoms is present in the matrix of the diamictite. Rare shell fragments are also present in this unit. Clast percentages are up to $25 \%$ and clasts are primarily composed of angular, indurated olive-green to olive-brown mudstone fragments $2-8 \mathrm{~mm}$ in size. Crystalline rock clasts as large as $7 \mathrm{~cm}$, including basalt and gneiss, are also present and have subrounded and faceted shapes.

\section{Interpretation}

The unconsolidated diamictons were probably deposited from floating ice and likely represent deposition from a floating glacier tongue or icebergs releasing debris over the site. The lamina of diatom ooze may be indicative of a brief period of open-marine conditions with high productivity and low terrigenous sedimentation rates.

\section{Unit II}

Interval: 318-U1360A-2R-1, $0 \mathrm{~cm}$, through 6R-CC, $26 \mathrm{~cm}$

Depth: 14.3-53.78 mbsf

Age: early Oligocene

The top of Unit II marks a sharp change in lithology and induration of the core, from unconsolidated diamicton above to carbonate-cemented claystone below. The strata in Unit II are generally well indurated, and carbonate-cemented beds are common. Five different lithofacies are recognized in a sequence from top to bottom in this unit:

1. Olive-green claystone with moderate bioturbation,

2. Dark green claystone with dispersed clasts,

3. Dark greenish gray sandy mudstone with dispersed clasts (Fig. F4),
4. Olive-brown sandstone with dispersed clasts (Fig. F5), and

5. Gray clast-rich sandy diamictite (Fig. F6).

Overall, Unit II can be characterized as a fining-upward sequence from diamictite at the base to claystone at the top. Clast and sand percentages decrease upsection throughout the unit. Bivalve shell fragments, some of which are pyritized, are common in the lower portion of Unit II, below interval 318-U1360A4R-1, $48 \mathrm{~cm}$. Clast lithologies are mainly gneiss, granite, diorite, and quartzite.

\section{Interpretation}

The lithofacies distribution present in Unit II is consistent with an ice-proximal to ice-distal glaciomarine depositional environment, similar to that described from the Oligocene and Miocene strata of the Victoria Land Basin, Ross Sea, Antarctica (Naish et al., 2001; Powell and Cooper, 2002).

\section{Clay mineralogy}

Five samples from Hole U1360A were prepared for $\mathrm{XRD}$ analysis of the clay fraction (i.e., one sample per core from Cores 318-U1360A-1R, 3R, 4R, 5R, and $6 \mathrm{R})$. The clay mineral assemblages in these samples are characterized by a mixture of all major clay mineral groups. The dominant clay-mineral components are smectite, illite, and chlorite, with a lesser contribution of kaolinite and pyrophyllite-talc (Fig. F7). Cores 318-U1360A-3R through 6R are assigned an early Oligocene age (see "Biostratigraphy"), and the clay mineral assemblages in these cores are similar to those reported from lower Oligocene shelf strata around the Antarctic margin (e.g., Hambrey et al., 1991; Ehrmann et al., 2005). The abundance of illite and chlorite is consistent with a glacial-marine depositional setting for the claystone, mudstone, sandstone, and diamictite facies described within Unit II. The relatively large contribution of talc, however, is not typical of Paleogene sediments on the Antarctic shelf and may reflect the weathering of a low-grade metamorphic facies, derived from a basic or ultrabasic igneous protolith, locally on the Wilkes Land margin or within the Wilkes subglacial basin.

\section{Biostratigraphy}

Cores 318-U1360A-1R through 5R (0-42.31 mbsf) contain siliceous microfossils (e.g., diatoms) (Table T2), whereas organic-walled microfossils (e.g., dinoflagellate cysts) are preserved in Cores 318-U1360A-1R through 6R (0-53.78 mbsf) (Table T3). Foraminifers were encountered only in Sample 318-U1360A-1RCC $(0.54 \mathrm{mbsf})$. Calcareous nannofossils are not present in Hole U1360A. Dinocysts and diatoms 
provide age control for Hole U1360A and indicate that Core $318-\mathrm{U} 1360 \mathrm{~A}-1 \mathrm{R}(0-0.54 \mathrm{mbsf})$ is of latest Pleistocene age, comprising a matrix with intraclasts of late Eocene to early Oligocene age. Samples 318U1360A-3R-1, $8 \mathrm{~cm}$, through 6R-CC (23.38-53.78 mbsf) are of early Oligocene $(<33.6 \mathrm{Ma})$ age. Sample 318 U1360A-2R-CC (14.30-14.52 mbsf) contains no agediagnostic diatoms but does contain typical heavily silicified Paleogene taxa, and because it falls within lithostratigraphic Unit II, the top of which is at $14.3 \mathrm{mbsf}$, and is assigned to early Oligocene. This implies a hiatus between Samples 318-U1360A-1RCC and 2R-CC, lasting from early Oligocene to latest Pleistocene.

\section{Siliceous microfossils}

Samples from Core 318-U1360A-1R (0-0.54 mbsf) contain abundant to common well-preserved diatoms, whereas Cores 2R through 5R (14.3-42.31 mbsf) contain trace to few diatoms (Table T2). Radiolarians are only preserved in Sample 318-U1360A-1R-CC (0.54 mbsf); Samples 6R-1, $81 \mathrm{~cm}$ (52.01 mbsf), and 6R-CC (53.78 mbsf) are barren of radiolarians.

\section{Diatoms, ebridians, silicoflagellates, chrysophyte cysts, and sponge spicules}

Thirteen samples from Hole U1360A were analyzed for diatoms, ebridians, silicoflagellates, chrysophyte cysts, and sponge spicules. All of these siliceous microfossil components were encountered in Hole U1360A. Silica-selective processing was carried out to concentrate the biosiliceous component for those samples in which analysis of smear slides indicated low biosilica content. Diatoms suggest the in situ sedimentary succession is uppermost Pleistocene for Core 318-U1360A-1R (0-0.54 mbsf) (Cody et al., 2008) and Oligocene for Sample 318-U1360A-3R-1, $8 \mathrm{~cm}$, through Core 5R (below $23.38 \mathrm{mbsf}$ ) (Scherer et al., 2000; Olney et al., 2007); dinocysts further constrain this lower section to the lower Oligocene (see below).

A characteristic latest Pleistocene Southern Ocean diatom flora (i.e., a mix of sea ice-associated and open-water taxa) is encountered in Samples 318U1360A-1R-1, $9 \mathrm{~cm}$ (0.09 mbsf), 1R-1, 19-20 cm (0.20 mbsf), and 1R-CC (0.54 mbsf), whereas a mixed latest Pleistocene/late Eocene to early Oligocene flora is found in Sample 1R-1, $17 \mathrm{~cm}$ (0.17 mbsf). The latter sample was taken from an intraclast (rather than the sedimentary matrix), accounting for the floral differences between this sample and the other three samples in Core 318-U1360A-1R (Table T2). Samples 318-U1360-3R-1, $8 \mathrm{~cm}$, through 5R-CC (23.38-42.31 mbsf) contain typical Oligocene Antarctic shallow-water siliceous microfossils similar to those recorded in the Cape Roberts Project CRP-2/2A drill core (Scherer et al., 2000; Olney et al., 2007).

\section{Core 318-U1360A-1R (0-0.54 mbsf): uppermost Pleistocene}

Samples taken from the sedimentary matrix of Core 318-U1360A-1R are characterized by trace to abundant, well-preserved latest Pleistocene index diatom taxa (e.g., Eucampia antarctica, Fragilariopsis curta, Fragilariopsis kerguelensis, Fragilariopsis rhombica, Fragilariopsis separanda, Thalassiosira antarctica, and Thalassiosira lentiginosa). The presence of $T$. antarctica (last occurrence [LO] at $0.61 \mathrm{Ma}$ ) constrains this core to the last 610 k.y., although the absence of Actinocyclus ingens ( $\mathrm{LO}$ at $0.54 \mathrm{Ma}$ ) may indicate a slightly younger age (i.e., the last 540 k.y.). Trace occurrences of the Paleogene diatom Pyxilla sp. and the Pliocene index diatoms Shionodiscus tetraoestrupii var. reimeri and Thalassiosira torokina in Sample 318-U1360A-1RCC indicate reworking of older material into the sedimentary matrix.

One sample was taken from an intraclast in Core 318-U1360A-1R (Sample 318-U1360A-1R-1, $17 \mathrm{~cm}$ ) (Table T2) that contains a mix of the latest Pleistocene diatom assemblage encountered in the matrix of Core 318-U1360A-1R (see above) plus moderately to well-preserved late Eocene to early Oligocene siliceous microfossils similar to those encountered in Samples 318-U1360A-3R-1, $8 \mathrm{~cm}$, through 5R-CC (see below). The late Eocene to early Oligocene age constraint is based on one specimen of Kisseleviella gaster (Olney et al., 2005) and is therefore rather tentative, although the assemblage associations provide supporting age evidence. In particular, Synedropsis cheethamii, a sea ice-associated diatom from lower Oligocene sediments of the Ross Sea (Olney et al., 2009), occurs in trace abundance alongside other small, lightly silicified pennates such as Kannoa hastata and Grammatophora sp. (Table T2), as well as heavily silicified taxa such as Pyxilla sp. and Hemiaulus sp. These associations are discussed below in context of Samples 318-U1360A-3R-1, $8 \mathrm{~cm}$, through $5 \mathrm{R}-\mathrm{CC}$. However, the finding is important because it shows that not only do some of the intraclasts in Core 318-U1360A-1R contain moderately to wellpreserved siliceous microfossils but that they also capture intriguing insights into Oligocene paleoenvironments at Site U1360.

\section{Samples 318-U1360A-2R-CC through 5R-CC (14.30- 42.31 mbsf): early Oligocene}

Sample 318-U1360A-2R-CC did not yield age-diagnostic microfossils but contains typical heavily silicified Paleogene taxa such as Hemiaulus spp., Pyxilla spp., and Stephanopyxis spp. We assign this sample to the 
Oligocene based on these assemblage associations and lack of latest Pleistocene diatoms present in Core 318-U1360A-1R. Samples 318-U1360A-3R-1, $8 \mathrm{~cm}$, through 5R-CC contain typical Oligocene Antarctic shallow water-shelf siliceous microfossils in trace to few abundance and moderate to good preservation. In Sample 318-U1360A-3R-1, 8 cm (23.38 mbsf), heavily silicified relatively large taxa such as Goniothecium odontella, Hemiaulus sp., Pyxilla sp., and Stephanopyxis sp. are preserved alongside more lightly silicified small pennates such as Fragilaria spp., Grammatophora spp., K. hastata, Kisseleviella spp., small Sceptroneis spp., and S. cheethamii. The paleoecology of these small pennates is largely unknown, but we suggest they could indicate low salinities (or possibly a sea ice environment, see below) because of morphological similarities to living freshwater and coastal taxa (Round et al., 1990; Olney et al., 2009). Low salinities are also indicated by the presence of Cocconeis sp. in Core 318-U1360A-4R (Table T2); further, the presence of the tychopelagic diatom taxa Actinoptychus senarius and Paralia sulcata suggest a shallow (near shore) environment. Importantly, if the identification of $S$. cheethamii is correct, it may indicate the presence of seasonal sea ice according to Olney et al. (2009), who described this species from lower Oligocene sediments of the Ross Sea. Scanning electron microscope analysis is required to confirm the identification of the small pennate diatoms in Hole U1360A because specific valve features were not resolvable in the light microscope on ship.

Trace occurrences of Kisseleviella cicatricata in Sample 318-U1360A-3R-1, $8 \mathrm{~cm}$ (23.38 mbsf) (Table T2), suggests an Oligocene age (Olney et al., 2005). This interpretation is corroborated by the presence of Rocella praenitida, although locally this species may range into the late middle Eocene according to unpublished data from Leg 189 Hole 1172A on the East Tasman Plateau (C.E. Stickley, pers. comm., 2010).

Considering that samples from Core 318-U1360A-3R downhole allow this part of lithostratigraphic Unit II to be assigned an early Oligocene age, we consider that the entire Unit II is of that age, including Sample 318-U1360A-2R-CC.

\section{Radiolarians}

Few radiolarians are found in Sample 318-U1360A1R-CC (0.54 mbsf). The assemblage is dominated by Antarctissa denticulata, suggesting an age no older than late Miocene. No additional age inferences are available from the radiolarian assemblages in Core 318-U1360A1R. Samples 318-U1360A-2R-CC through 6R-CC are barren of radiolarians.

\section{Palynology}

Six samples from Hole U1360A were processed for palynology (Table T3). All samples yield few to common organic-walled dinocysts. Sporomorphs are present in common (Sample 318-U1360A-1R-CC) to trace (Sample 6R-1, 31-33 cm) abundances. Preservation of both sporomorphs and dinocysts is good in all samples.

\section{Organic-walled dinocysts}

Dinocyst assemblages within all samples consist of abundant Brigantedinium spp., Selenopemphix spp., and Lejeunecysta sp. A ("large"). The identification of Forma T sensu Goodman and Ford (1983) in Samples 318U1360A-1R-CC through 6R-CC (0.54-53.78 mbsf) suggests the entire cored succession in Hole U1360A is early Oligocene $(<33.6 \mathrm{Ma})$ in age (see "Biostratigraphy" in the "Site U1356" chapter). Lejeunecysta sp. A ("large") was found consistently, in agreement with lower Oligocene records at Site U1356. This indicates that Lejeunecysta sp. A ("large") is a reliable index species for the early Oligocene in this region. Diatom investigations indicate that the sediments in Sample 318-U1360A-1R-1, $17 \mathrm{~cm}$ (0.17 mbsf), comprise an uppermost Pleistocene matrix with intraclasts of late Eocene to early Oligocene age. We thus consider that the early Oligocene dinocysts found in Sample 318-U1360A-1R-CC (0.54 mbsf) may originate from the intraclasts. No dinocyst index species for the latest Pleistocene were recorded within Sample 318-U1360A-1R-CC.

Sample 318-U1360A-6R-CC (53.78 mbsf) contains relatively high abundances of Spinidinium macmurdoense, Spinidinium schellenbergii, and Vozzhennikovia spp. Although the specimens are well preserved and intact, they may be reworked from older strata.

Sporomorphs in the samples investigated comprise few specimens of Nothofagus and saccate pollen; these may be reworked from Eocene strata and/or represent contemporaneous vegetation in the hinterland (cf. Prebble et al., 2006). Other palynofacies components were found in trace amounts only.

\section{Foraminifers}

Shipboard examination of core catcher samples identified well-preserved planktonic and benthic foraminifers in Sample 318-U1360A-1R-CC (0.54 mbsf) only; Samples 2R-CC through 6R-CC are barren of foraminifers.

\section{Planktonic foraminifers}

Planktonic foraminifer assemblages in Sample 318U1360A-1R-CC (0.54 mbsf) comprise a monospecific assemblage of the extant foraminifer Neogloboquadrina 
pachyderma (first occurrence at $9.4 \mathrm{Ma}$; Chron C4Ar.1n) (Berggren et al., 1995; Gradstein et al., 2004). Based on this taxon, Sample 318-U1360A-1RCC is assigned to Subantarctic Zone AN7, which ranges from the middle late Miocene to present, concurring with a latest Pleistocene diatom-based age for Core 318-U1360A-1R.

\section{Benthic foraminifers}

Sample 318-U1360A-1R-CC (0.54 mbsf) contains a lowdiversity calcareous benthic foraminifer assemblage, with Globocassidulina subglobosa as the dominant species ( $40 \%$ of the total assemblage). Rare specimens of Trifarina angulosa and Cibicidoides mundulus were also found. Since they are well preserved, we argue that the benthic foraminifers in Sample 318-U1360A-1R-CC (0.54 mbsf) originate from the uppermost Pleistocene matrix, rather than the intraclast material.

\section{Paleoenvironmental interpretation}

\section{Latest Pleistocene}

The latest Pleistocene diatom assemblages are a mix of sea ice-associated and open-water taxa, implying that the shelf setting at Site U1360 was influenced by seasonal sea ice. Benthic foraminifer assemblages comprising high abundances of G. subglobosa are typically associated with Antarctic Bottom Water (Corliss, 1979). Because Antarctic Bottom Water formation is linked to seasonal sea ice formation, this corroborates a seasonally sea ice-influenced environment.

\section{Early Oligocene}

The early Oligocene diatom assemblages contain shallow water-shelf taxa, indicating low-salinity conditions and likely seasonal sea ice. The dominance of protoperidinioid dinocysts indicates high surface water nutrient levels and possibly sea ice because these taxa are heterotrophic. Sporomorphs represent reworking from older strata and/or contemporaneous vegetation in the hinterland.

\section{Summary}

Sediments in Core 318-U1360A-1R (0-0.54 mbsf) comprise an uppermost Pleistocene matrix with intraclasts of late Eocene to early Oligocene age. Diatoms indicate that during the latest Pleistocene, the shelf setting of Site U1360 was influenced by seasonal sea ice. Combined microfossil analyses suggest the interval below Sample 318-U1360A-3R-1, $8 \mathrm{~cm}$ (23.38 mbsf), is early Oligocene $(<33.6 \mathrm{Ma})$ in age. Diatom assemblage associations and lithostratigraphy suggest all of the strata below $14.3 \mathrm{mbsf}$ is early Oligocene in age. The early Oligocene microfossils indicate a shallow-water shelfal environment with low salinities and high nutrient levels, likely driven by seasonal sea ice. Sporomorphs may represent reworking from older strata and/or contemporaneous vegetation in the hinterland.

\section{Paleomagnetism}

We took only two samples from Hole U1360A (Samples 318-U1360A-4R-1, $15 \mathrm{~cm}$, and 4R-2, $72 \mathrm{~cm}$ ). The samples were subjected to step-wise demagnetization (Fig. F8). Both samples had reverse polarity consistent with Chron C12r, as predicted by the biostratigraphy (see "Biostratigraphy").

\section{Geochemistry \\ Organic geochemistry}

Gas analysis was performed on two cores from Hole U1360A using the methods described in "Geochemistry and microbiology" in the "Methods" chapter. Methane concentrations in Cores 318-U1360A-4R and 6R were 118 and 494 ppmv, respectively.

\section{Inorganic geochemistry}

Three sediment samples in Hole U1360A were taken for analyses of weight percent carbonate and major and trace element analyses (silicon, titanium, aluminum, iron, calcium, magnesium, sodium, potassium, phosphorus, strontium, barium, vanadium, scandium, and cobalt). Data are reported in Table T4.

\section{Physical properties}

The physical properties program for Site U1360 included routine runs on the Whole-Round Multisensor Logger (WRMSL), which includes GRA bulk density, magnetic susceptibility, and $P$-wave velocity logger (PWL) sensors, as well as natural gamma radiation (NGR) measurements. $P$-wave velocity was also analyzed and samples taken for moisture, density, and porosity measurements.

\section{Whole-Round Multisensor Logger measurements}

\section{Magnetic susceptibility}

Whole-core magnetic susceptibility was measured at $2.5 \mathrm{~cm}$ intervals ( $2 \mathrm{~s}$ measurement time). Raw data values range from 6 to 2518 instrument units. However, the majority of values vary between 30 and 320 instrument units (Fig. F9), with peaks in Cores 318U1360A-5R and 6R where gravel clasts occur. The fining-upward sequence from diamictites at the base (Core 318-U1360A-6R) to claystones at the top 
(Cores 2R through 3R) (see "Lithostratigraphy") is also documented in the general decrease in magnetic susceptibility values from the bottom to the top of the hole.

\section{Natural gamma radiation}

NGR counts range from 33 to 99 cps, with the majority between 15 and $45 \mathrm{cps}$, as plotted in Figure F9.

\section{Gamma ray attenuation bulk density}

GRA density was measured at $2.5 \mathrm{~cm}$ intervals using a $10 \mathrm{~s}$ integration time. Variations in GRA density reflect variations in lithology between clast-rich diamictite, sandy mudstone with dispersed clasts, and claystone. The values are as high as $2.48 \mathrm{~g} / \mathrm{cm}^{3}$ (Fig. F10).

\section{P-wave velocity}

$P$-wave velocity measurements were made at $5 \mathrm{~cm}$ intervals on the PWL on the WRMSL. These measurements range from 1633 to $2767 \mathrm{~m} / \mathrm{s}$ (Fig. F11). Additionally, split-core $P$-wave velocity measurements were taken using the Section Half Velocity Gantry. These measurements, taken one per section, range from 1699 to $8658 \mathrm{~m} / \mathrm{s}$. In general, all measurements correlate well (Fig. F11).

\section{Moisture and density measurements}

Measurements of density, porosity, and grain density were undertaken on five samples taken from cores of Hole U1360A. Dependent on core recovery and quality, one sample was taken per section. These samples were measured for wet mass, dry mass, and dry volume and, using these measurements, porosity, percent water mass, dry density, bulk density, and grain density were calculated.

The bulk densities from discrete samples are plotted in Fig. F10, range from 1.83 to $2.58 \mathrm{~g} / \mathrm{cm}^{3}$, and show a slight elevation above the values measured by the GRA densiometer. GRA density results are consistently lower than those measured from discrete samples. We interpret this to be a result of the reduced diameter of the RCB cores. This reduced diameter likely systematically underestimated the bulk density as measured by the GRA density meter.

Calculated porosity ranges from $49 \%$ to $17 \%$ and generally decreases with depth (Fig. F12). Grain densities range between 2.62 and $2.7 \mathrm{~g} / \mathrm{cm}^{3}$. The higher grain density $\left(3.13 \mathrm{~g} / \mathrm{cm}^{3}\right)$ in a sample from Core $318-\mathrm{U} 1360-4 \mathrm{R}$ is most likely related to the occurrence of pyrite in the sediment (up to $8 \%$; see "Lithostratigraphy").

\section{References}

Berggren, W.A., Kent, D.V., Swisher, C.C., III, and Aubry, M.-P., 1995. A revised Cenozoic geochronology and chronostratigraphy. In Berggren, W.A., Kent, D.V., Aubry, M.-P., and Hardenbol, J. (Eds.), Geochronology, Time Scales and Global Stratigraphic Correlation. Spec. Publ.-SEPM (Soc. Sediment. Geol.), 54:129-212.

Cody, R.D., Levy, R.H., Harwood, D.M., and Sadler, P.M., 2008. Thinking outside the zone: high-resolution quantitative diatom biochronology for the Antarctic Neogene. Palaeogeogr., Palaeoclimatol., Palaeoecol., 260(12):92-121. doi:10.1016/j.palaeo.2007.08.020

Corliss, B.H., 1979. Recent deep-sea benthonic foraminiferal distributions in the southeast Indian Ocean: inferred bottom-water routes and ecological implications. Mar. Geol., 31(1-2):115-138. doi:10.1016/ 0025-3227(79)90059-8

De Santis, L., Brancolini, G., and Donda, F., 2003. Seismostratigraphic analysis of the Wilkes Land Continental Margin (East Antarctica): influence of glacially driven processes on the Cenozoic deposition. Deep-Sea Res., Part II, 50(8-9):1563-1594. doi:10.1016/S09670645(03)00079-1

Ehrmann, W., Setti, M., and Marinoni, L., 2005. Clay minerals in Cenozoic sediments off Cape Roberts (McMurdo Sound, Antarctica) reveal palaeoclimatic history. Palaeogeogr., Palaeoclimatol., Palaeoecol., 229(3):187-211. doi:10.1016/j.palaeo.2005.06.022

Eittreim, S.L., Cooper, A.K., and Wannesson, J., 1995. Seismic stratigraphic evidence of ice-sheet advances on the Wilkes Land margin of Antarctica. Sediment. Geol., 96(12):131-156. doi:10.1016/0037-0738(94)00130-M

Escutia, C., De Santis, L., Donda, F., Dunbar, R.B., Cooper, A.K., Brancolini, G., and Eittreim, S.L., 2005. Cenozoic ice sheet history from East Antarctic Wilkes Land Continental Margin sediments. Global Planet. Change, 45(13):51-81. doi:10.1016/j.gloplacha.2004.09.010

Escutia, C., Eittreim, S.L., and Cooper, A.K., 1997. Cenozoic sedimentation on the Wilkes Land continental rise, Antarctica. In Ricci, C.A. (Ed.), The Antarctic Region: Geological Evolution and Processes. Proc. Int. Symp. Antarct. Earth Sci., 7:791-795.

Exon, N.F., Kennett, J.P., Malone, M.J., et al., 2001. Proc. ODP, Init. Repts., 189: College Station, TX (Ocean Drilling Program). doi:10.2973/odp.proc.ir.189.2001

Goodman, D.K., and Ford, L.N., Jr., 1983. Preliminary dinoflagellate biostratigraphy for the middle Eocene to lower Oligocene from the southwest Altantic Ocean. In Ludwig, W.J., Krasheninnikov, V.A., et al., Init. Repts. DSDP, 71: Washington, DC (U.S. Govt. Printing Office), 859-977. doi:10.2973/dsdp.proc.71.131.1983

Gradstein, F.M., Ogg, J.G., and Smith, A. (Eds.), 2004. A Geologic Time Scale 2004: Cambridge (Cambridge Univ. Press). http://cambridge.org/uk/catalogue/catalogue.asp? isbn=9780521781428

Hambrey, M.J., Ehrmann, W.U., and Larsen, B., 1991. Cenozoic glacial record of the Prydz Bay continental shelf, East Antarctica. In Barron, J., Larsen, B., et al., 
Proc. ODP, Sci. Results, 119: College Station, TX (Ocean Drilling Program), 77-132. doi:10.2973/

odp.proc.sr.119.200.1991

Hayes, D.E., Frakes, L.A., et al., 1975. Init. Repts. DSDP, 28: Washington, DC (U.S. Govt. Printing Office). doi:10.2973/dsdp.proc.28.1975

Mallinson, D.J., Flower, B., Hine, A., Brooks, G., and Molina Garza, R., 2003. Paleoclimate implications of high latitude precession-scale mineralogic fluctuations during early Oligocene Antarctic glaciation: the Great Australian Bight record. Glob. Planet. Change 39(34):257-269. doi:10.1016/S0921-8181(03)00119-X

Naish, T.R., Woolfe, K.J., Barrett, P.J., Wilson, G.S., Atkins, C., Bohaty, S.M., Bücker, C.J., Claps, M., Davey, F.J., Dunbar, G.B., Dunn, A.G., Fielding, C.R., Florindo, F., Hannah, M.J., Harwood, D.M., Henrys, S.A., Krissek, L.A., Lavelle, M., van der Meer, J., McIntosh, W.C., Niessen, F., Passchier, S., Powell, R.D., Roberts, A.P., Sagnotti, L., Scherer, R.P., Strong, C.P., Talarico, F., Verosub, K.L., Villa, G., Watkins, D.K., Webb, P.-N., and Wonik, T., 2001. Orbitally induced oscillations in the East Antarctic Ice Sheet at the Oligocene/Miocene boundary. Nature (London, U. K.), 413(6857):719-723. doi:10.1038/ 35099534

O'Brien, P.E., Cooper, A.K., Richter, C., et al., 2001. Proc. ODP, Init. Repts., 188: College Station, TX (Ocean Drilling Program). doi:10.2973/odp.proc.ir.188.2001

Olney, M.P., Bohaty, S.M., Harwood, D.M., and Scherer, R.P., 2009. Creania lacyae gen. nov. et sp. nov. and Synedropsis cheethamii sp. nov., fossil indicators of Antarctic sea ice? Diatom Res., 24(2):357-375.
Olney, M.P., Scherer, R.P., Bohaty, S.M., and Harwood, D.M., 2005. Eocene-Oligocene paleoecology and the diatom genus Kisseleviella Sheshukova-Poretskaya from the Victoria Land Basin, Antarctica. Mar. Micropaleontol., 58(1):56-72. doi:10.1016/j.marmicro.2005.09.003

Olney, M.P., Scherer, R.P., Harwood, D.M., and Bohaty, S.M., 2007. Oligocene-early Miocene Antarctic nearshore diatom biostratigraphy. Deep-Sea Res., Part II, 54(21-22):2325-2349. doi:10.1016/j.dsr2.2007.07.020

Powell, R.D., and Cooper, J.M., 2002. A glacial sequence stratigraphic model for temperate, glaciated continental shelves. In Dowdeswell, J.A., and O'Cofaigh, C. (Eds.), Glacier-Influenced Sedimentation on High-Latitude Continental Margins. Geol. Soc. Spec. Publ., 203:215-244. doi:10.1144/GSL.SP.2002.203.01.12

Prebble, J.G., Raine, J.I., Barrett, P.J., and Hannah, M.J., 2006. Vegetation and climate from two Oligocene glacioeustatic sedimentary cycles (31 and $24 \mathrm{Ma}$ ) cored by the Cape Roberts Project, Victoria Land Basin, Antarctica. Palaeogeogr., Palaeoclimatol., Palaeoecol., 231(12):41-57. doi:10.1016/j.palaeo.2005.07.025

Round, F.E., Crawford, R.M., and Mann, D.G., 1990. The Diatoms: Biology and Morphology of the Genera: Cambridge (Cambridge Univ. Press).

Scherer, R.P., Bohaty, S.M., and Harwood, D.M., 2000. Oligocene and lower Miocene siliceous microfossil biostratigraphy of Cape Roberts Project core CRP-2/2A, Victoria Land Basin, Antarctica. Terra Antart., 7(4):417-442.

Publication: 2 July 2011

MS 318-108 
Figure F1. Bathymetric map of eastern Wilkes Land continental shelf showing the location of Sites U1357, U1358, and U1360. Bold black line = multichannel seismic reflection Profile IFP 108 shown in Figure F2 and Figure F2 in the "Site U1358" chapter.

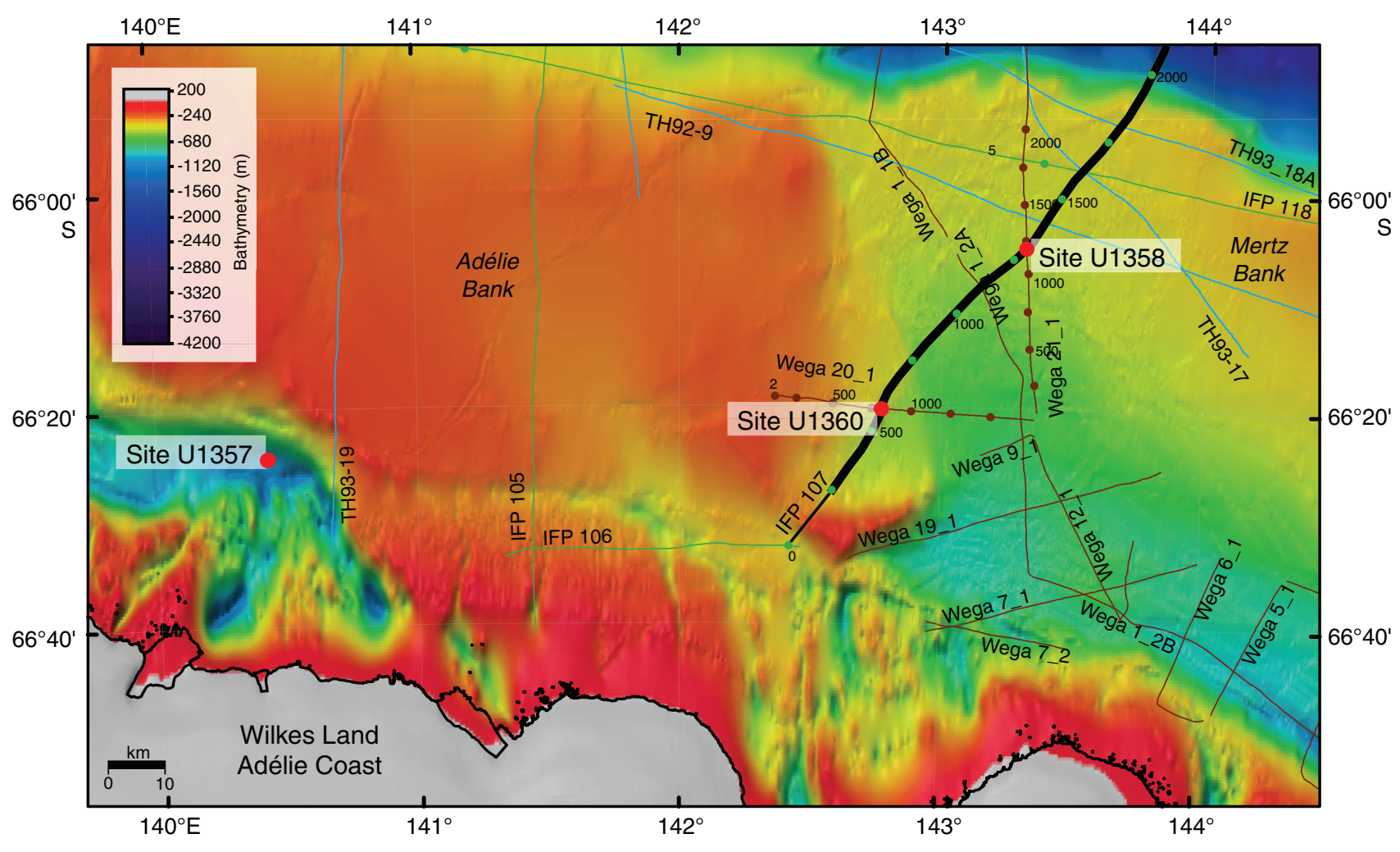


Figure F2. Multichannel seismic reflection Profile IFP 107 across Site U1360. Profile shows the main regional unconformities defined in the Wilkes Land continental shelf. Drilling at Site U1360 targeted unconformity WL-U3. Red rectangle = approximate penetration achieved at Site U1360. Location of seismic profile is shown in Figure F1.

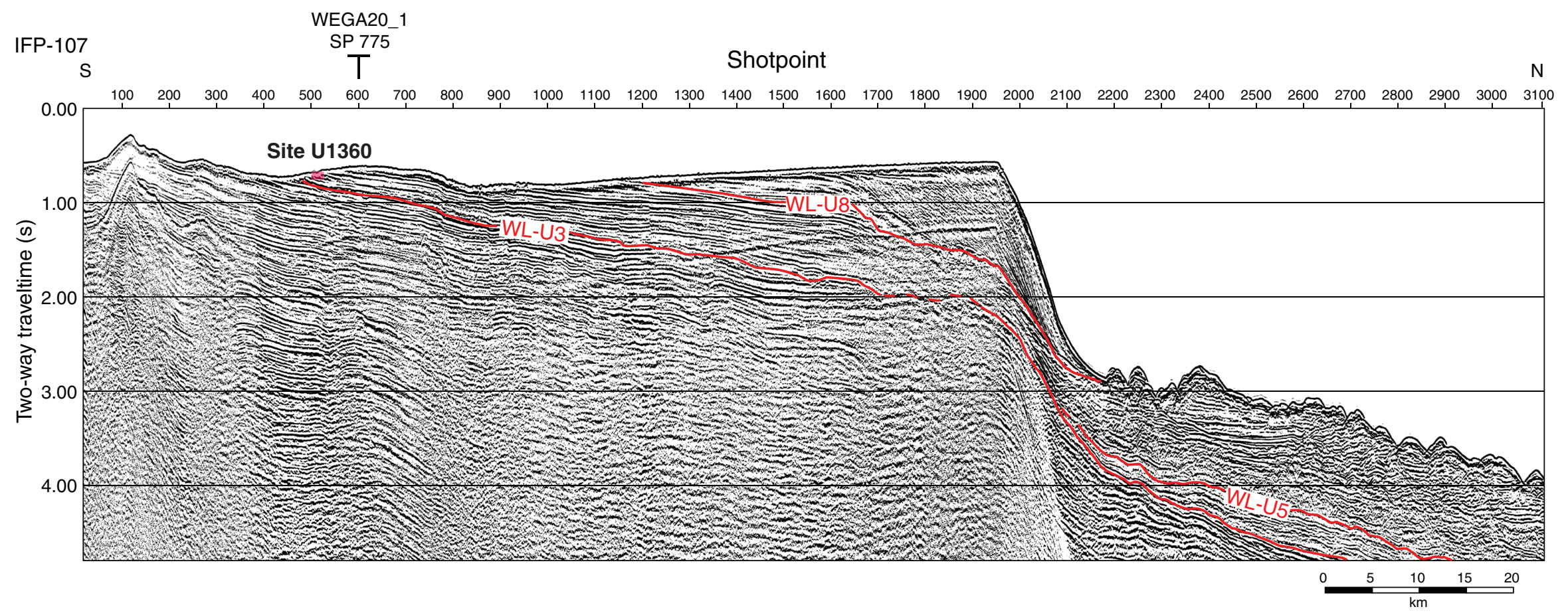


Figure F3. Core image of diamicton (interval 318-U1360A-1R-1, 17-23 cm) with yellowish diatom ooze lamination, Hole U1360A (interval 318-U1360A-1R-1, 18-20 cm).

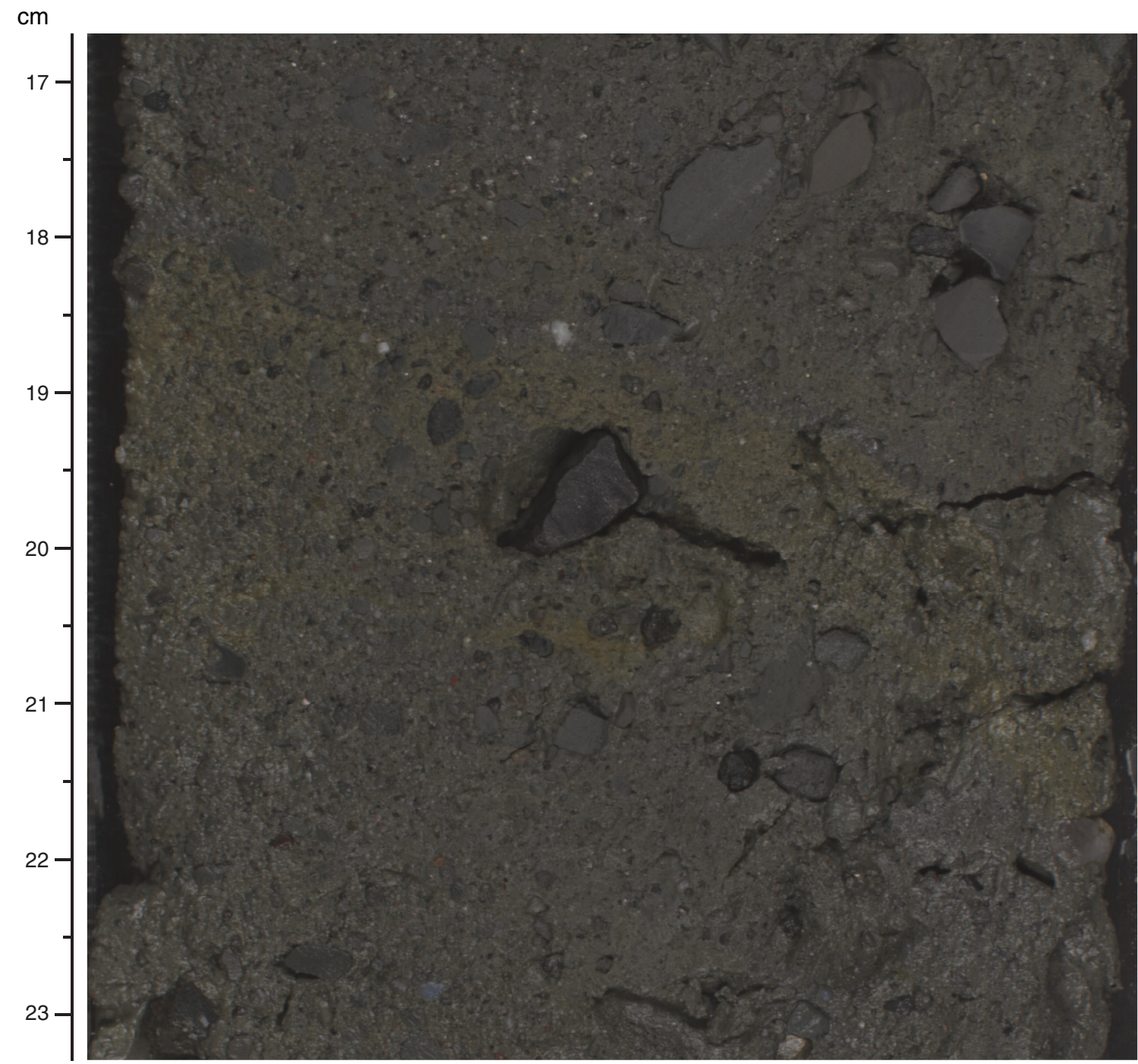


Figure F4. Core image of sandy mudstone with dispersed clasts, Hole U1360A (interval 318-U1360A-4R-2, 67$81 \mathrm{~cm})$.

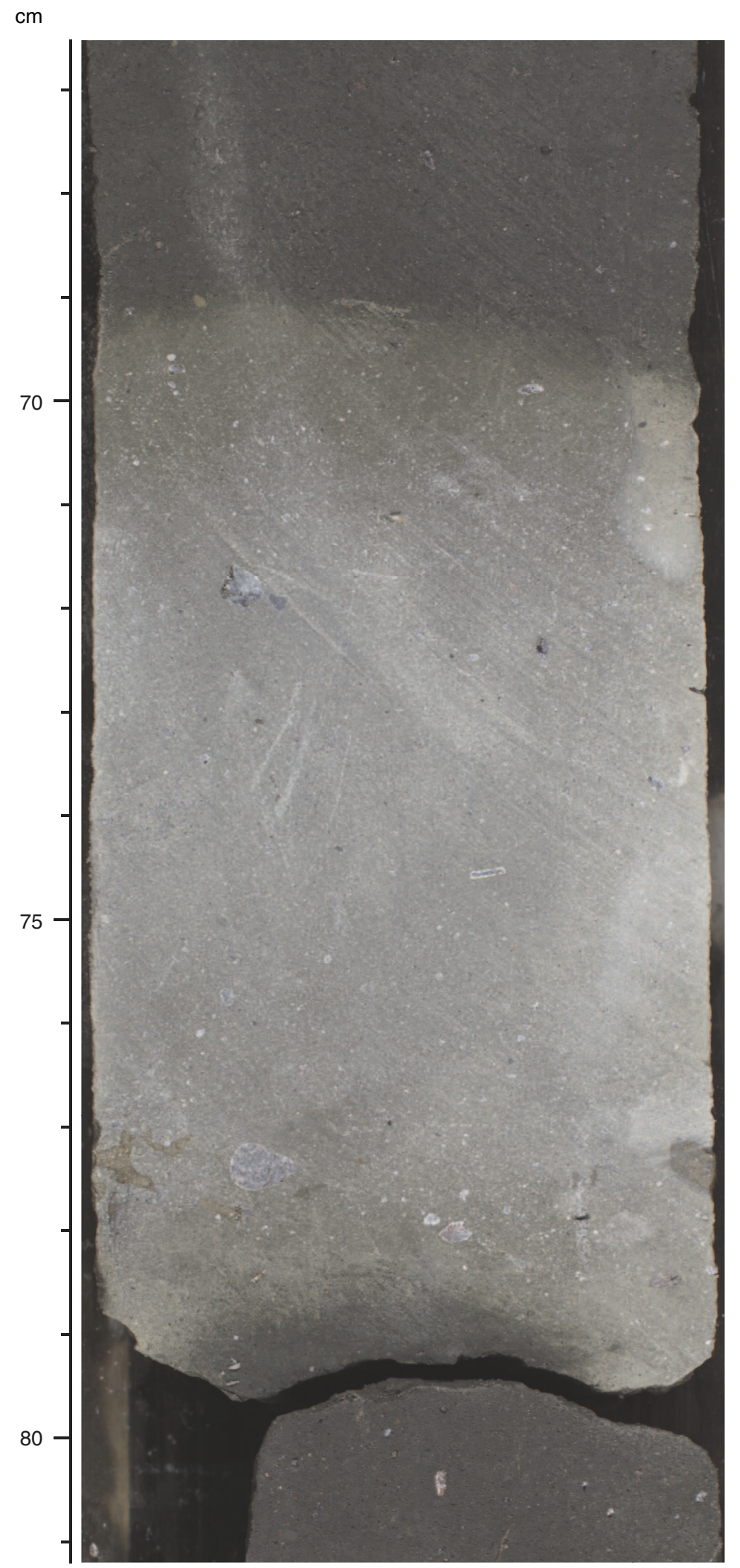


Figure F5. Core image of sandstone with dispersed clasts, Hole U1360A (interval 318-U1360A-6R-1, 33-43 cm).

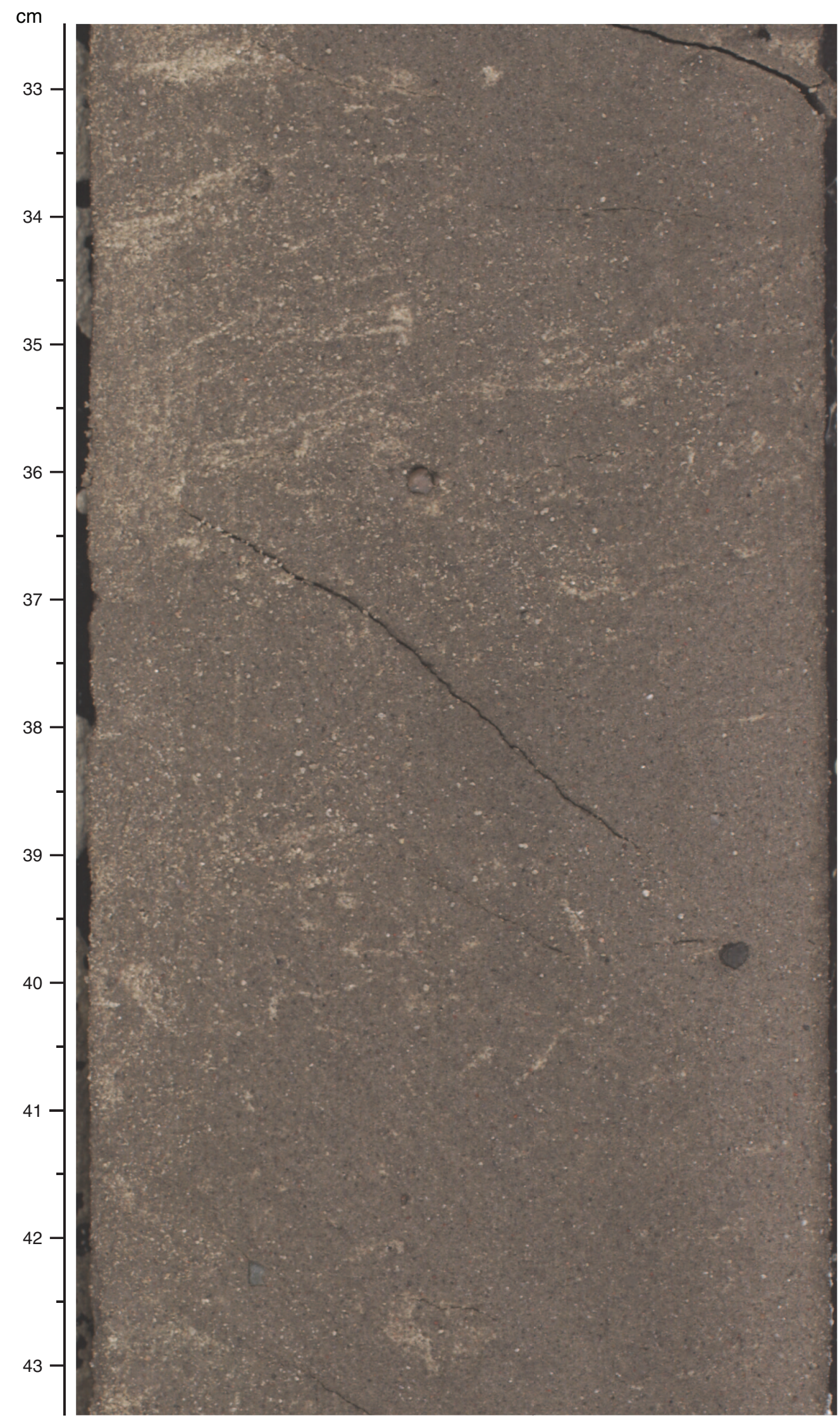


Figure F6. Core image of diamictite, Hole U1360A (interval 318-U1360A-6R-CC, 3-13 cm).

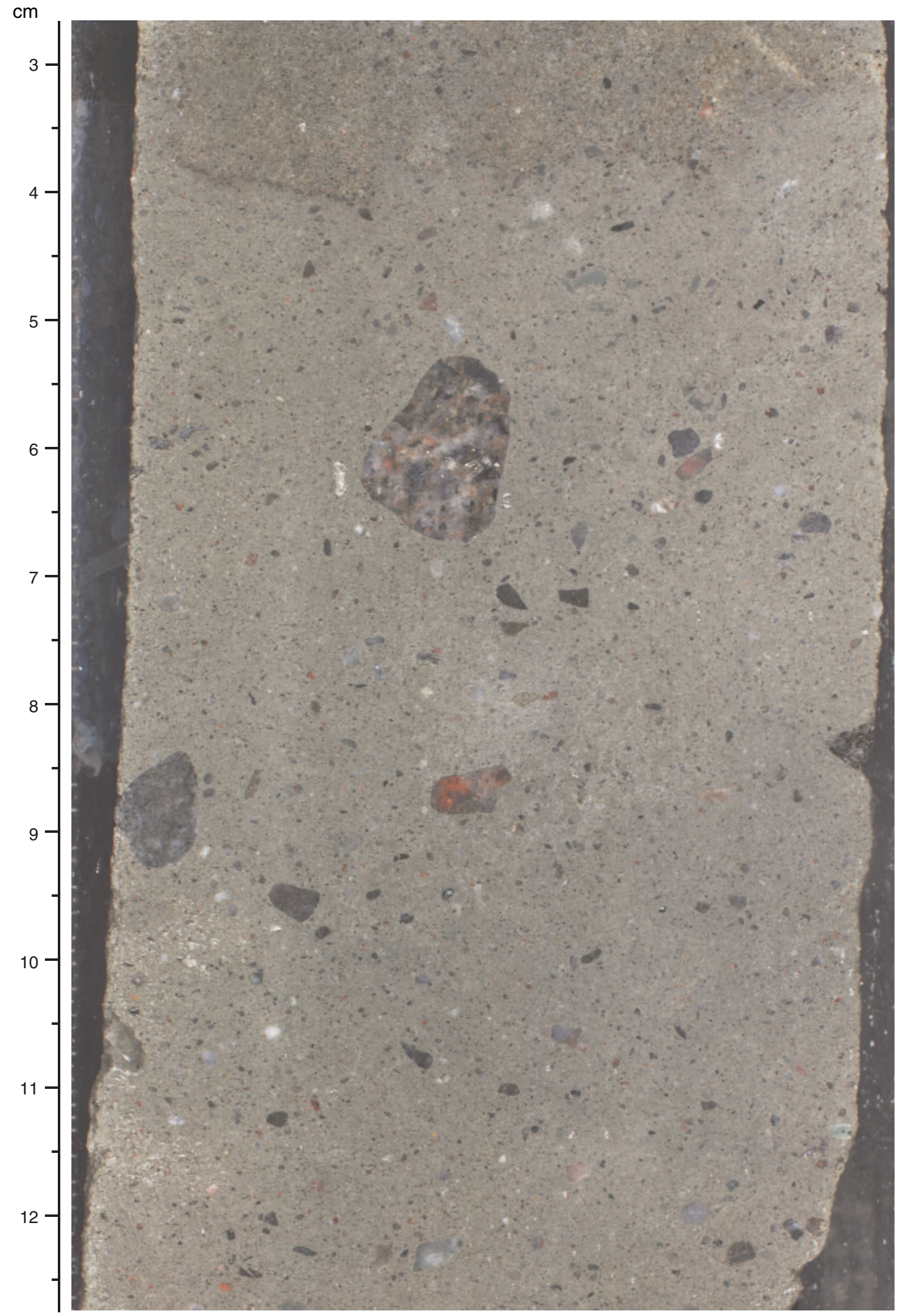


Figure F7. Clay mineral assemblage record, Hole U1360A. Peak heights were summed and normalized to an arbitrary unit of 10 , and the peak height for each mineral group was recalculated as a fractional component of this sum.

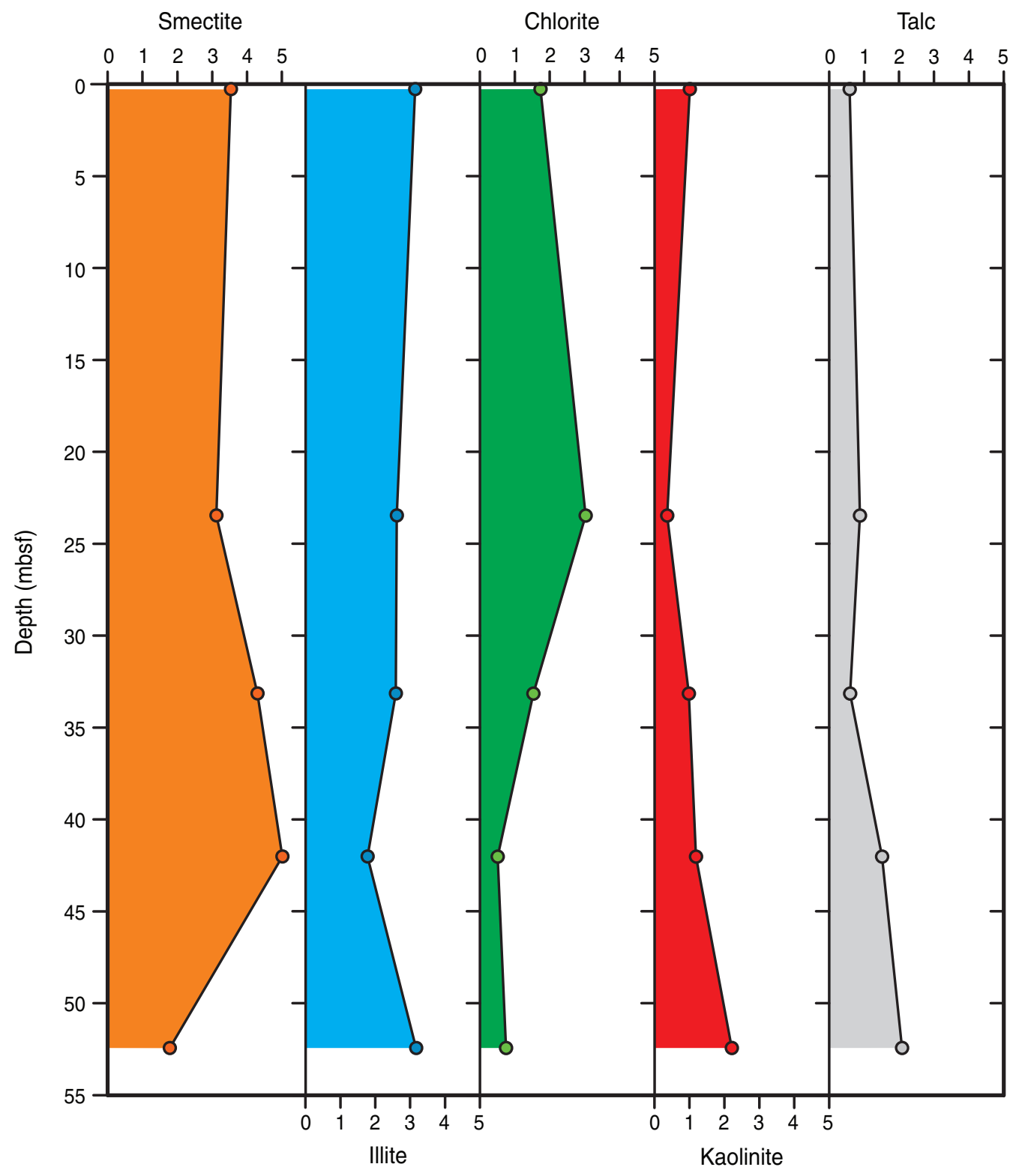



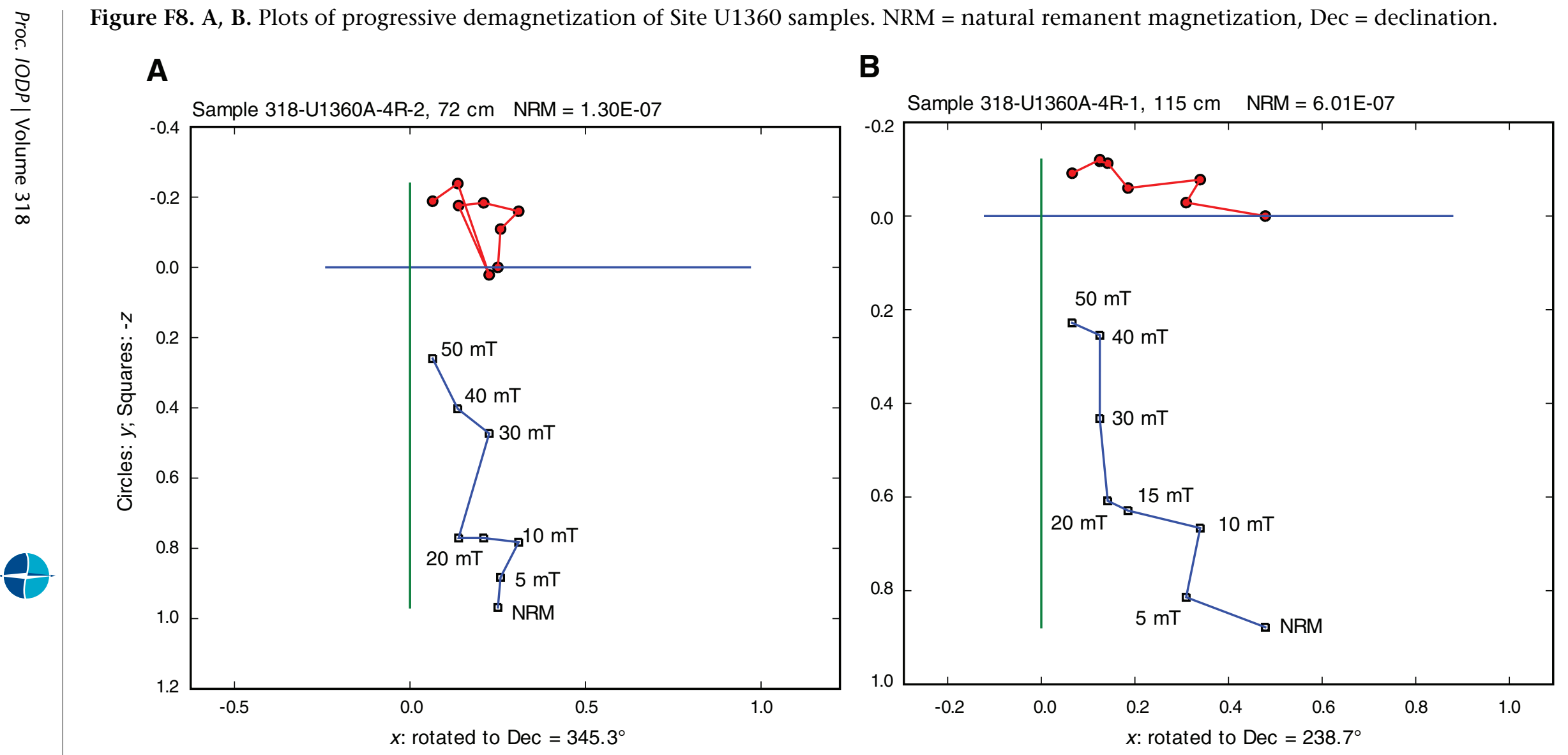
Figure F9. Plots of magnetic susceptibility and natural gamma radiation (NGR) data, Hole U1360A.
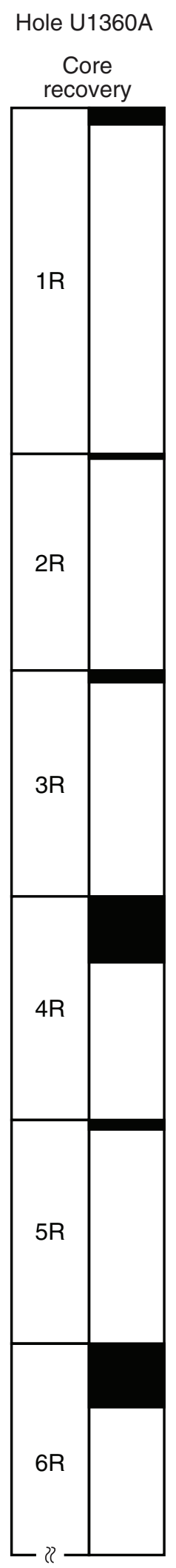
Magnetic susceptibility
(instrument units)

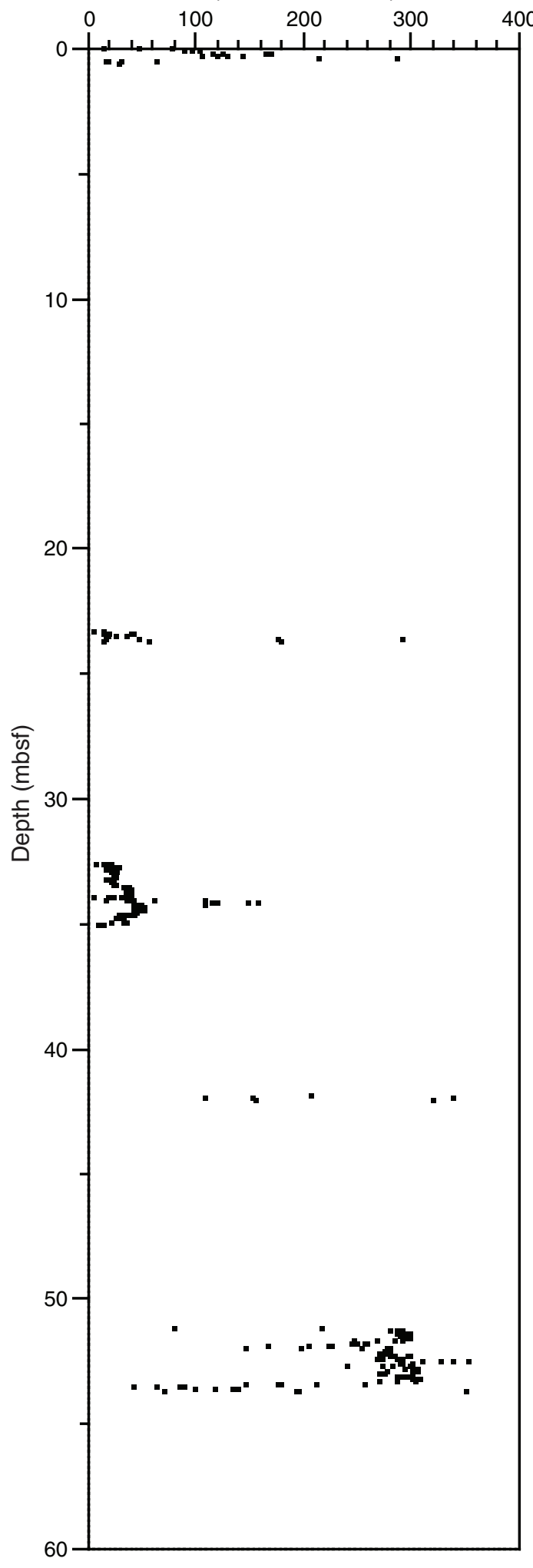

NGR

(cps)

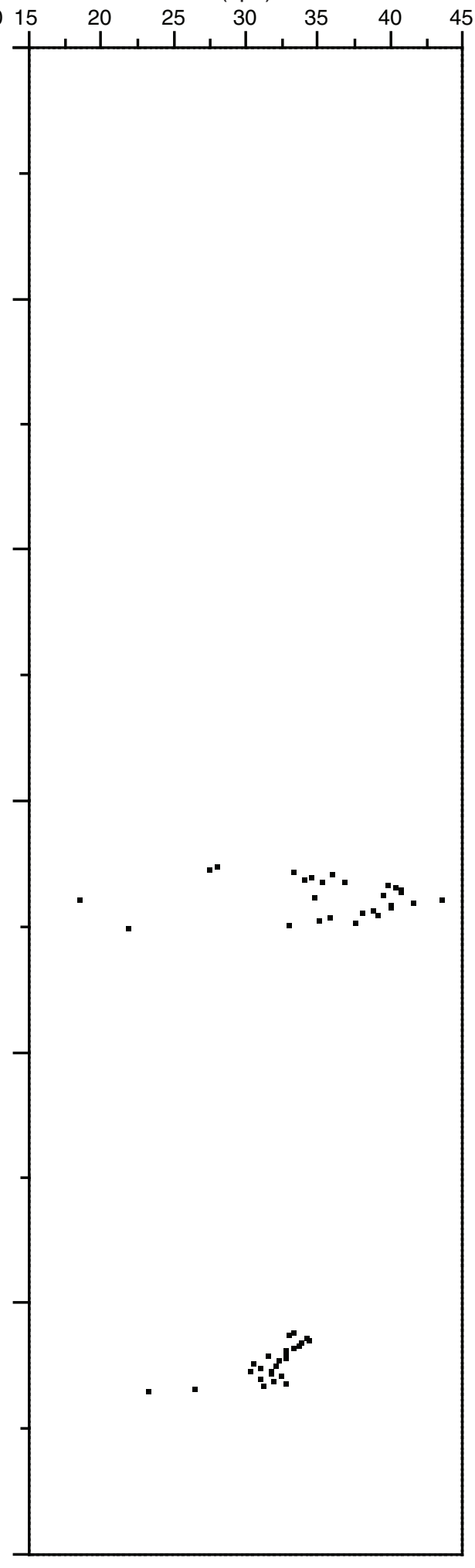


Figure F10. Plots of GRA bulk density (black squares) and discrete measurements bulk density (red circles), Hole U1360A.

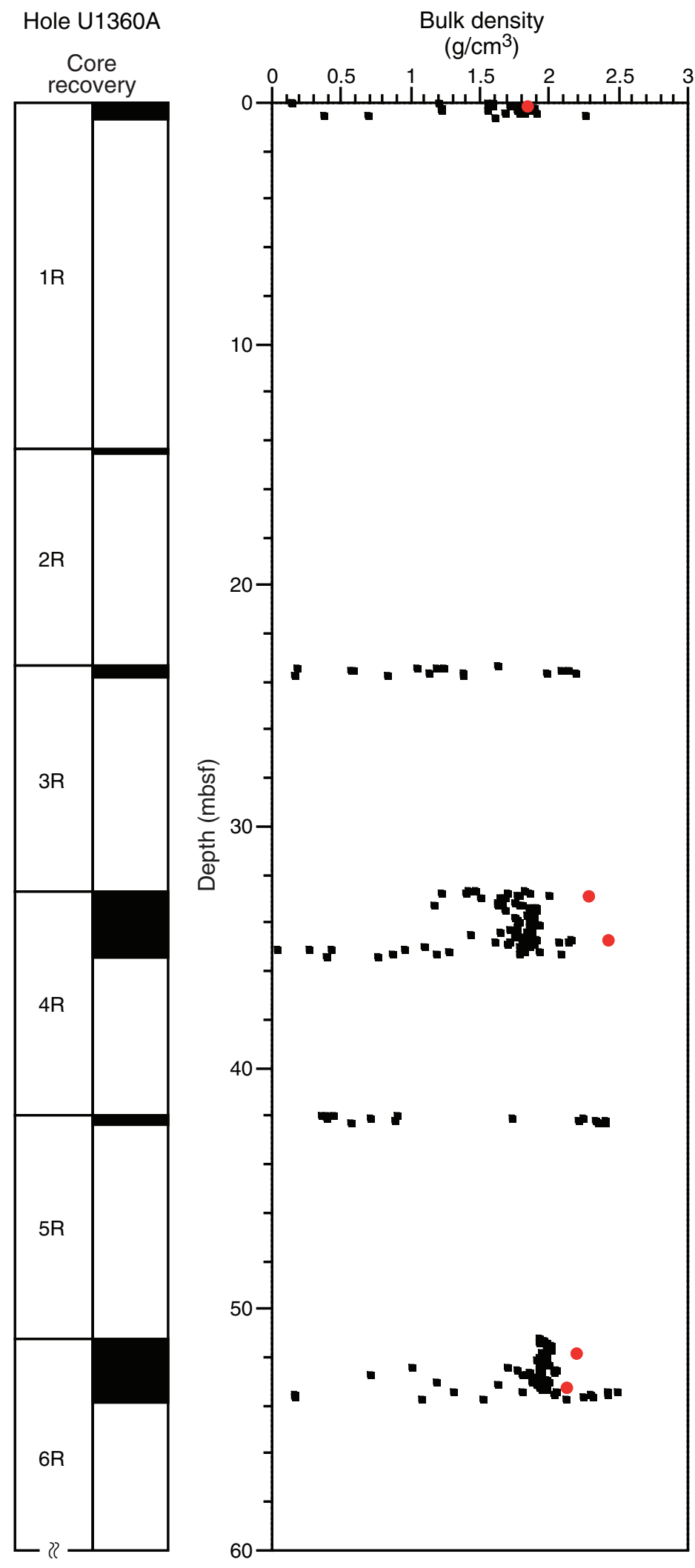


Figure F11. Plot of P-wave logger (PWL) and Section Half Velocity Gantry data, Hole U1360A.

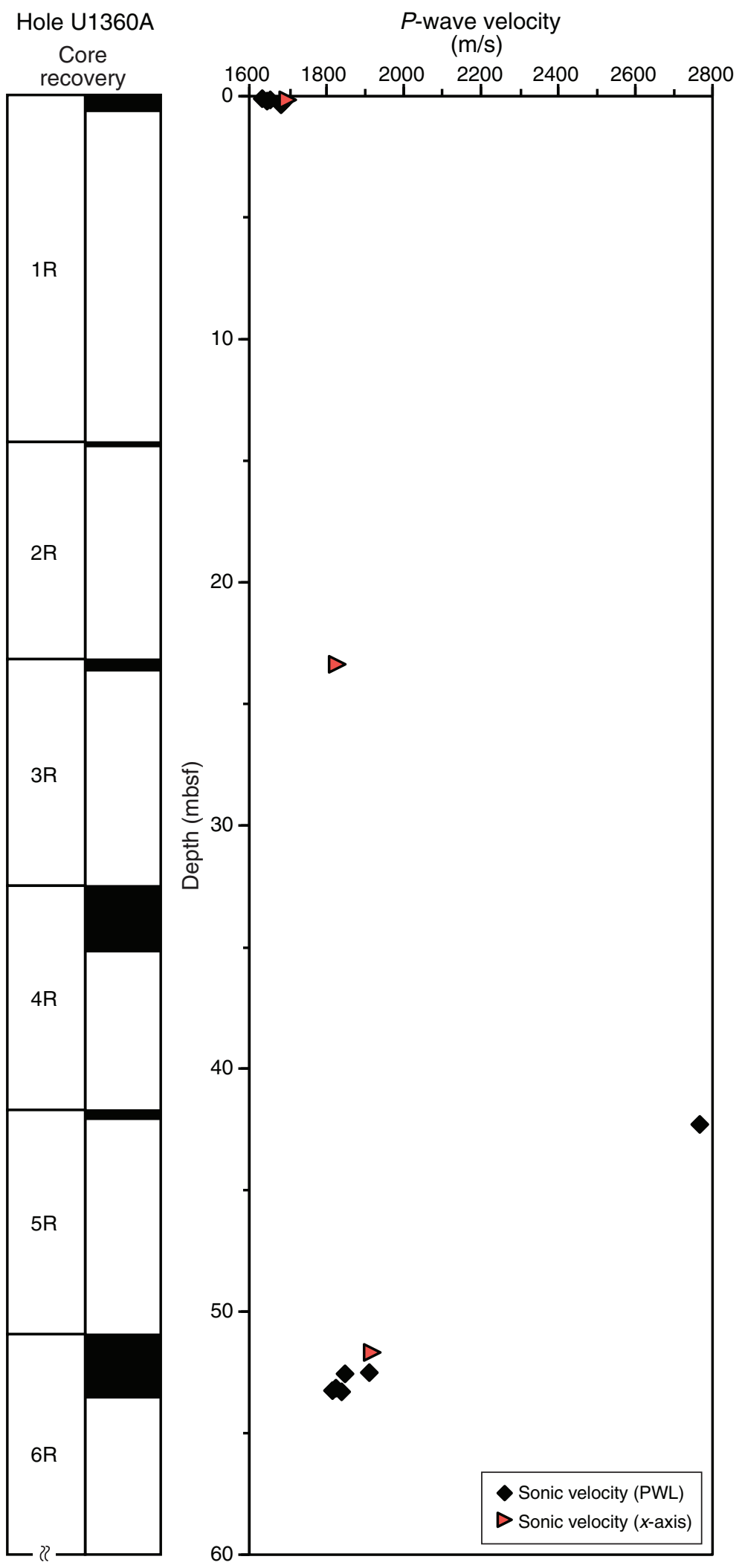


Figure F12. Plots of grain density and porosity from discrete samples, Hole U1360A.

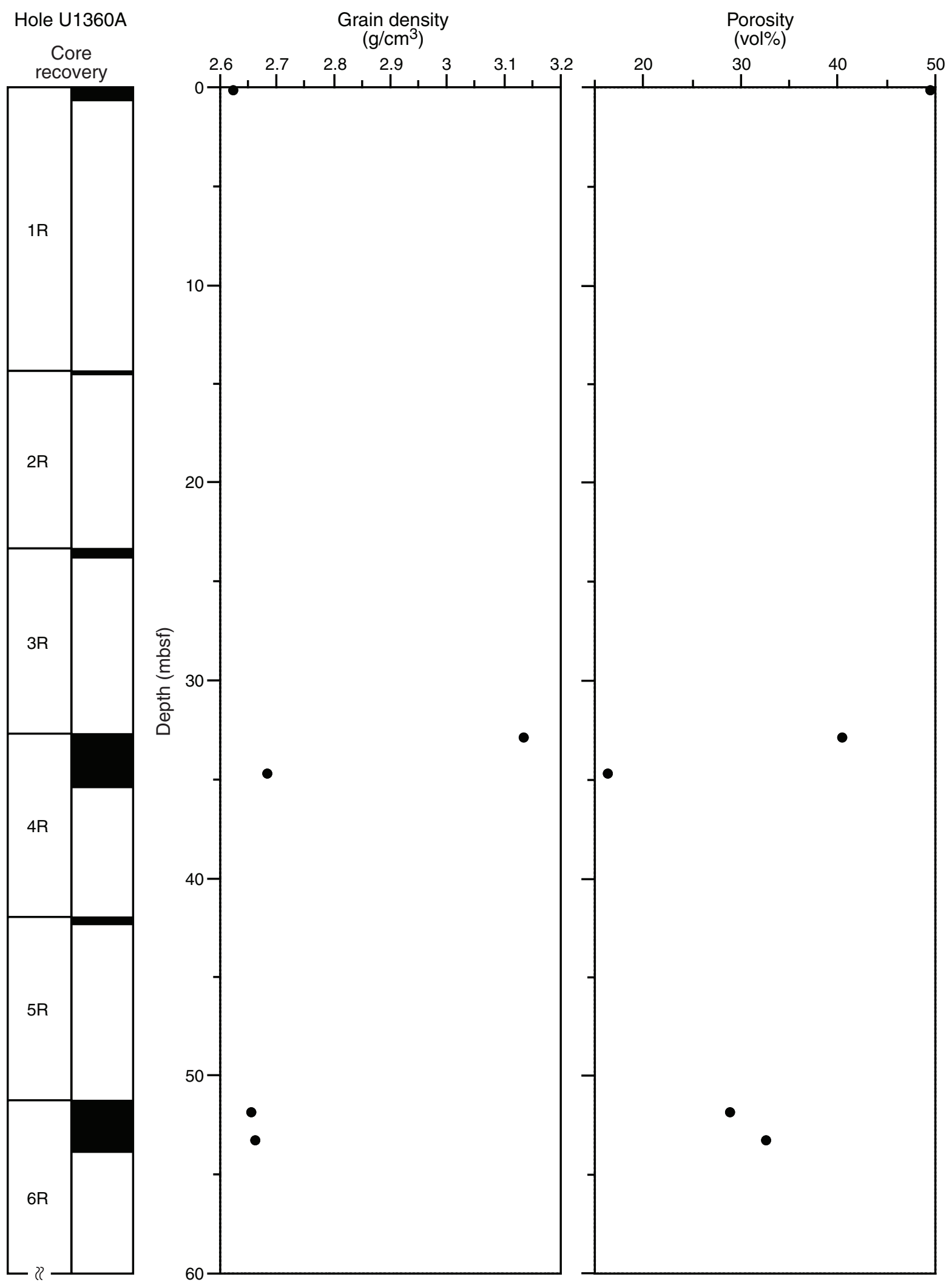


Table T1. Coring summary, Site U1360. (See table notes.)

\begin{tabular}{|c|c|c|c|c|c|c|c|c|c|}
\hline \multicolumn{10}{|c|}{$\begin{array}{l}\text { Site U1360 } \\
\quad \text { Time on site (h): } 31.0 \text { ( } 2315 \text { h, } 12 \text { February-0615 h, } 14 \text { February } 2010)\end{array}$} \\
\hline $\begin{array}{c}\text { Hole U } \\
\text { Latitu } \\
\text { Long } \\
\text { Time } \\
\text { Seafl } \\
\text { Dista } \\
\text { Wate } \\
\text { Total } \\
\text { Total } \\
\text { Total } \\
\text { Total } \\
\text { Core } \\
\text { Total }\end{array}$ & $\begin{array}{l}360 \mathrm{~A} \\
\text { de: } 66^{\circ} 22 \\
\text { ude: } 142 \\
\text { on hole (h } \\
\text { or (drill pi } \\
\text { ce betwe } \\
\text { depth (d } \\
\text { enetratio } \\
\text { lepth (dri } \\
\text { ength of } \\
\text { ore recov } \\
\text { ecovery ( } \\
\text { umber o }\end{array}$ & $\begin{array}{l}0395^{\prime} \mathrm{S} \\
44.7050^{\prime} \mathrm{E} \\
: 31.0 \text { ( } 231 \\
\text { ee measuren } \\
\text { n rig floor a } \\
\text { II pipe meas } \\
\text { (m DSF): } 7 \\
\text { pipe meast } \\
\text { ored section } \\
\text { red (m): } 7 . \\
\text { o): } 10 \\
\text { cores: } 7\end{array}$ & $\begin{array}{l}h, 12 \text { Fel } \\
\text { ent from } \\
\text { id sea lev } \\
\text { urement } f \\
.8 \\
\text { eement fr } \\
\text { (m): } 70.8\end{array}$ & $\begin{array}{l}\text { ruary-0615 h } \\
\text { rig floor, m DP } \\
\text { (m): } 11.0 \\
\text { om sea level, } \\
\text { m rig floor, m }\end{array}$ & $\begin{array}{l}\text { h, } 14 \text { Febru } \\
\text { RF): } 506.0 \\
m \text { ): } 495.0 \\
\text { m DRF): } 576\end{array}$ & ry 2010) & & & \\
\hline Core & $\begin{array}{l}\text { Date } \\
(2010)\end{array}$ & $\begin{array}{l}\text { Local time } \\
\text { (h) }\end{array}$ & $\begin{array}{c}\text { Depth } \\
\text { Top of } \\
\text { cored } \\
\text { interval }\end{array}$ & $\begin{array}{l}\text { Bottom of } \\
\text { cored } \\
\text { interval }\end{array}$ & $\begin{array}{l}\text { Interval } \\
\text { advanced } \\
(\mathrm{m})\end{array}$ & $\begin{array}{l}\text { Depth } \\
\text { Top of } \\
\text { cored } \\
\text { interval }\end{array}$ & $\begin{array}{c}\text { SFF-A (m) } \\
\text { Bottom of } \\
\text { cored } \\
\text { interval }\end{array}$ & $\begin{array}{l}\text { Length of core } \\
\text { recovered } \\
\text { (m) }\end{array}$ & $\begin{array}{l}\text { Recovery } \\
\quad(\%)\end{array}$ \\
\hline \multicolumn{10}{|c|}{ 318-U1360A- } \\
\hline $1 \mathrm{R}$ & 13 Feb & 0650 & 0.0 & 14.3 & 14.3 & 0.00 & 0.60 & 0.60 & 4 \\
\hline $2 \mathrm{R}$ & $13 \mathrm{Feb}$ & 1005 & 14.3 & 23.3 & 9.0 & 14.30 & 14.52 & 0.22 & 2 \\
\hline $3 \mathrm{R}$ & $13 \mathrm{Feb}$ & 1320 & 23.3 & 32.6 & 9.3 & 23.30 & 23.76 & 0.46 & 5 \\
\hline $4 \mathrm{R}$ & $13 \mathrm{Feb}$ & 1745 & 32.6 & 41.9 & 9.3 & 32.60 & 35.36 & 2.76 & 30 \\
\hline $5 \mathrm{R}$ & $13 \mathrm{Feb}$ & 1915 & 41.9 & 51.2 & 9.3 & 41.90 & 42.31 & 0.41 & 4 \\
\hline $6 \mathrm{R}$ & 13 Feb & 2015 & 51.2 & 61.0 & 9.8 & 51.20 & 53.78 & 2.58 & 26 \\
\hline \multirow[t]{2}{*}{$7 R$} & 13 Feb & 2200 & 61.0 & 70.8 & 9.8 & 61.00 & 61.00 & 0.00 & 0 \\
\hline & & & Total in & $\begin{array}{l}\text { Cored totals: } \\
\text { terval cored: }\end{array}$ & $\begin{array}{l}70.8 \\
70.8\end{array}$ & & & 7.03 & 10 \\
\hline
\end{tabular}

Notes: DRF = drilling depth below rig floor. DSF-A = drilling depth below seafloor determined by tagging seafloor, CSF-A $=$ core depth below seafloor, overlap if long. Local time $=$ UTC $+11 \mathrm{~h}$.

Table T2. Siliceous microfossil abundance and preservation, Hole U1360A. This table is available in an oversized format. 
Table T3. Palynology, Hole U1360A. (See table notes.)

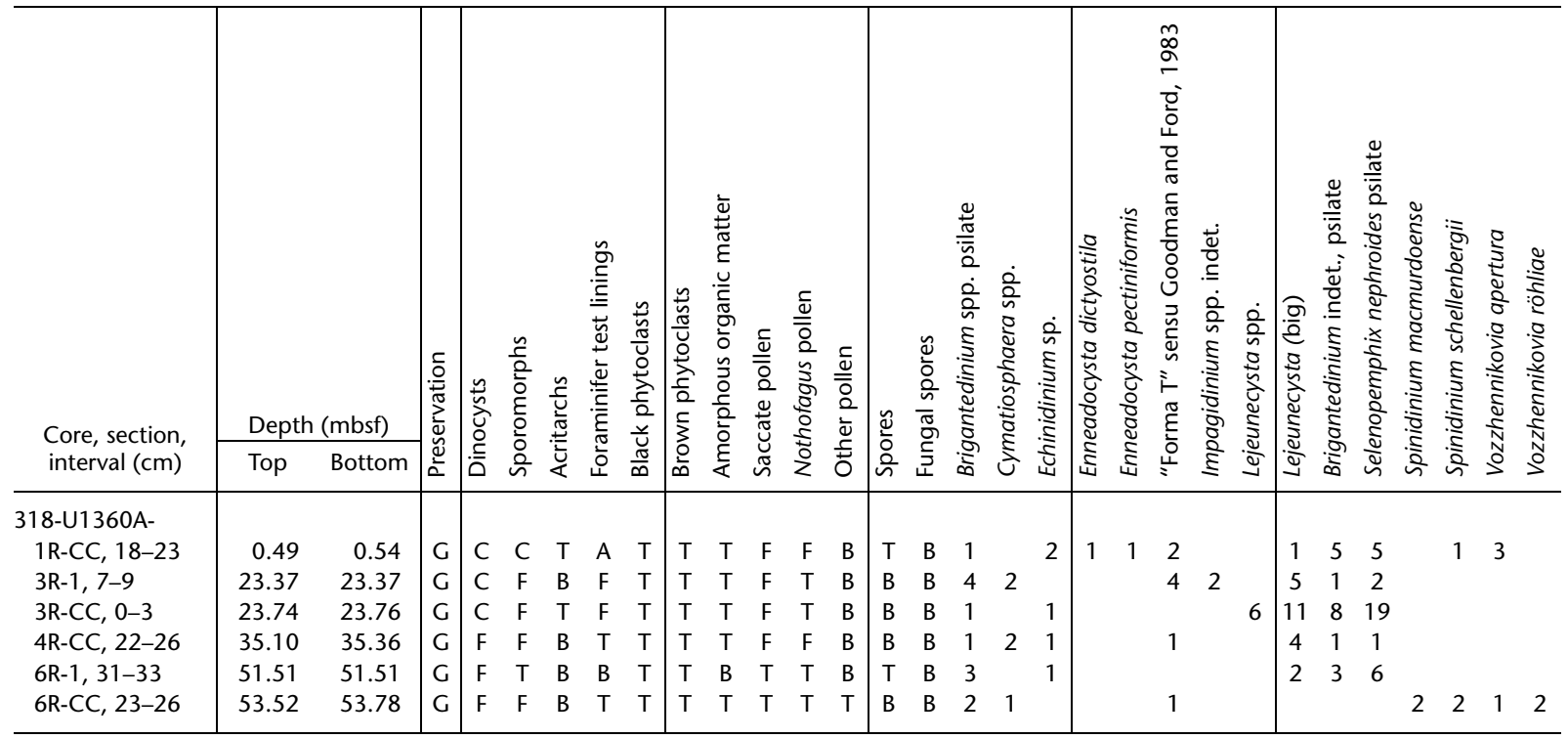

Notes: Preservation: $\mathrm{G}=$ good. Abundance: $\mathrm{A}=$ Abundant, $\mathrm{C}=$ common, $\mathrm{F}=\mathrm{few}, \mathrm{T}=$ trace, $\mathrm{B}=$ barren. See "Biostratigraphy" in the "Methods" chapter for preservation and abundance definitions.

Table T4. Major and trace element concentrations, Site U1360. (See table notes.)

\begin{tabular}{|c|c|c|c|c|c|c|c|c|c|c|c|c|c|c|c|c|}
\hline \multirow{2}{*}{$\begin{array}{l}\text { Core, section, } \\
\text { interval }(\mathrm{cm})\end{array}$} & \multirow{2}{*}{$\begin{array}{l}\text { Depth } \\
\text { (mbsf) }\end{array}$} & \multicolumn{9}{|c|}{ Major element oxide (wt\%) } & \multicolumn{5}{|c|}{ Trace element (ppm) } & \multirow{2}{*}{$\begin{array}{l}\mathrm{CaCO}_{3} \\
\text { (wt\%) }\end{array}$} \\
\hline & & $\mathrm{SiO}_{2}$ & $\mathrm{TiO}_{2}$ & $\mathrm{Al}_{2} \mathrm{O}_{3}$ & $\mathrm{Fe}_{2} \mathrm{O}_{3}$ & $\mathrm{MgO}$ & $\mathrm{CaO}$ & $\mathrm{Na}_{2} \mathrm{O}$ & $\mathrm{K}_{2} \mathrm{O}$ & $\mathrm{P}_{2} \mathrm{O}_{5}$ & $\mathrm{Ba}$ & $\mathrm{Sr}$ & $\mathrm{V}$ & Sc & Co & \\
\hline \multicolumn{17}{|l|}{ 318-U1360A- } \\
\hline $1 \mathrm{R}-4,27-28$ & 0.27 & 76.56 & 0.47 & 10.45 & 4.41 & 1.71 & 1.85 & 1.95 & 2.40 & 0.13 & 389 & 112 & 78 & 11 & 17 & 0.69 \\
\hline $4 R-1,55-57$ & 33.15 & 75.42 & 0.56 & 11.48 & 3.91 & 1.79 & 2.22 & 2.01 & 2.44 & 0.12 & 443 & 190 & 93 & 14 & 8 & 0.07 \\
\hline $6 \mathrm{R}-1,123.5-124.5$ & 52.44 & 85.94 & 0.35 & 6.28 & 2.49 & 0.51 & 1.04 & 1.27 & 2.01 & 0.07 & 389 & 122 & 39 & 5 & 3 & 0.48 \\
\hline
\end{tabular}

Notes: Major element oxides normalized to 100 wt $\%$. Typical errors are $1 \%-5 \%$ for all elements over the course of two ICP-AES runs during which the samples were analyzed. $\mathrm{CaCO}_{3}$ contents were determined by coulometer. 